\title{
Tracking the long-term structure changes of a mature deciduous broadleaf forest stand using digital hemispherical photography
}

\author{
Mait Lang ${ }^{1,2 *}$ and Jan Pisek ${ }^{1}$
}

Lang, M., Pisek, J. 2019. Tracking the long-term structure changes of a mature deciduous broadleaf forest stand using digital hemispherical photography. - Forestry Studies | Metsanduslikud Uurimused 70, 80-87, ISSN 1406-9954. Journal homepage: http://mi.emu.ee/ forestry.studies

\begin{abstract}
Hemispherical photography provides permanent records of forest canopy structure. We analysed digital hemispherical images taken during the period of 2007-2018 in a mature silver birch stand located in Järvselja, Estonia. The stand was thinned in 2004. Understory trees were removed in the spring of 2018. Images were processed using the LinearRatio ${ }_{\mathrm{SC}}$ method. Effective plant area index $L^{\text {eff }}$ during the leafless phenophase increased as a result of tree growth from 0.92 to 1.24 and understory cutting was not detectable. During the full foliage condition $L^{\text {eff }}$ increased from 3.6 in 2008 to 5.8 in 2017. After removal of understory trees from the stand $L^{\text {eff }}$ decreased, and repeated measurements in the summer of 2018 estimated the plant area index range $4.5<L^{\text {eff }}<4.8$. The results are in agreement with the expected changes following forest growth and demonstrate that LinearRatio ${ }_{\mathrm{SC}}$ is a suitable method for the estimation and long-term monitoring of forest canopy properties from digital hemispherical images.
\end{abstract}

Key words: phenology, photographic measurements, LinearRatio ${ }_{\mathrm{SC}^{\prime}} \mathrm{RAMI}^{\mathrm{R}}$ irch forest, plant area index.

Authors' addresses: ${ }^{1}$ Tartu Observatory, Faculty of Science and Technology, University of Tartu, 61602 Tõravere, Tartumaa, Estonia; ${ }^{2}$ Chair of Forest Management Planning and Wood Processing Technologies, Institute of Forestry and Rural Engineering, Estonian University of Life Sciences, Kreutzwaldi 5, 51006 Tartu, Estonia; *e-mail: lang@to.ee

\section{Introduction}

Terrestrial data on plant canopy structure are required for the validation of remote sensing data based leaf area index estimates (Fernandes et al., 2014) and modeling of ecosystem processes (Härkönen et al., 2019). Digital hemispherical photography was proposed for plant canopy measurements by Evans \& Coombe (1959). The method was further developed by Anderson (1964) to estimate the radiation regime in forests. The radiation regime is determined by the fraction of gaps in canopy that depend on the leaf area index (Nilson, 1971). Gap fraction $t(\theta)$ can be calculated as a ratio from the below- and above-canopy radiation measurements (Welles \& Norman, 1991) using plant canopy analysers. Kuusk et al. (2018) showed that substantial 
discrepancies exist between estimates of $t(\theta)$ when using different optical methods. Cescatti (2007) published the LinearRatio method and showed how to use two digital hemispherical cameras as a pair of plant canopy structure analyser devices. Lang et al. (2010) proposed LinearRatio ${ }_{\mathrm{SC}}$ and showed that above-canopy reference can be reconstructed using sky radiance values sampled from canopy gaps. LinearRatio has been tested in deciduous forests (Lang et al., 2013) and coniferous forests (Lang et al., 2017). LinearRatio ${ }_{\mathrm{SC}}$ has been used for the estimation of canopy gap fraction in beech forests (Lukasová et al., 2014) and for the estimation of canopy cover in mixed forests (Arumäe \& Lang, 2018; Lallemand et al., 2017).

We have taken photographic measurements of transmitted visible radiation using an upward-looking hemispherical camera since 2007 in a mature deciduous forest stand in Järvselja, South-East Estonia. The changes in the forest stand structure were determined merely by tree growth after thinning in 2004 (Kuusk et al., 2013) and the removal of the understory tree layer in the spring of 2018. We expect corresponding changes in the plant area index estimated from canopy gap fraction data.

\section{Material and Methods}

The site has been included in the RAdiative transfer Model Intercomparison (RAMI) exercise (Widlowski et al., 2015) for benchmarking of radiative transfer models. The deciduous broadleaf stand is growing on a fertile typical brown soil. The dominant tree species is silver birch (Betula pendula Roth) accompanied by black alder (Alnus glutinosa (L.) Gaertn.) and European aspen (Populus tremula L.) trees. The upper layer of trees was $25 \mathrm{~m}$ high in 2007. The stand was thinned in September-October 2004 (Kuusk et al., 2008; 2013). Improved light conditions at the forest floor have stimulated the growth of the stand lower tree layer which consists mainly of Tilia cordata Mill., Prunus padus L., Corylus avellana L., Acer platanoides L. and Fraxinus excelsior L. which are all shade-tolerant trees. In March 2018 we removed the understory trees that had a stem diameter at breast height of less than $4 \mathrm{~cm}$, since the broad horizontal leaves of the lower layer were blocking the view to the upper layer which has served as the test structure in our modelling experiments.

There are nine marked sampling points in the stand which were used to take hemispherical images with Canon EOS 5D and Sigma 8 mm F3.5 EX DG lens. The height of the camera lens was 1.2-1.3 meters from ground level. Some examples of the images can be found in the Appendix of the paper. The camera calibration details are described in Lang et al. (2010). The camera was operated in manual mode and the exposure settings (ISO, shutter speed and aperture size) were set to ensure pixel maximum value within the interquartile range of the camera dynamic range (Lang et al., 2017). The decision data for this simple rule were obtained visually from the image histograms during the field measurements. The measurements were done exclusively during diffuse illumination conditions (Table 1) and data were stored into sensor raw files.

Measurement data were processed with Hemispherical Project Manager - a free software (available at Tartu Observatory webpage) which enables implementation of LinearRatio ${ }_{S C}$. The pixel values were first extracted with dcraw 9.17 (Coffin, 2014) without colour interpolation and brightness scaling (-D switch). Dark frames values were subtracted (-K switch) and the 16-bit linear output was selected (-4 switch). Authentic blue pixels were sampled according to the sensor filter pattern. Circular fisheye images were obtained after correcting for projection distortion and vignetting. Next, marks were inserted into canopy gaps to sample unobscured sky pixel values for the reconstruction of the above-canopy reference images similarly to Lang et al. (2010; 2017). Canopy 
gap fraction was then calculated as a ratio between the below-canopy image and the reconstructed above-canopy image. The average gap fraction for each pixel of the nine images was used for analysis for each measurement date.

Table 1. Measurements. The label "S" indicates the phenophase with all leaves attached and " $W$ " is for the time after autumn foliage fall and before spring bud burst.

\begin{tabular}{|c|c|c|}
\hline Date & $\begin{array}{l}\text { Pheno- } \\
\text { phase }\end{array}$ & Comments \\
\hline 2007.11 .22 & W & Overcast \\
\hline 2008.08 .15 & $\mathrm{~S}$ & Obscured sunset \\
\hline 2008.11.19 & W & $\begin{array}{l}\text { Overcast. Traces of snow } \\
\text { on trunks. }\end{array}$ \\
\hline 2009.04 .14 & W & Obscured sunset \\
\hline 2009.07.30 & $S$ & Sunset \\
\hline 2010.08 .02 & S & Sunset \\
\hline 2011.04.27 & W & Sunset \\
\hline 2013.08 .05 & $S$ & $\begin{array}{l}\text { Overcast, slight } \\
\text { brightening towards the } \\
\text { Sun }\end{array}$ \\
\hline 2015.04 .22 & W & Overcast \\
\hline 2015.07.01 & S & $\begin{array}{l}\text { Overcast, variable } \\
\text { illumination }\end{array}$ \\
\hline 2015.07 .03 & $S$ & Sunset \\
\hline 2016.07 .29 & $S$ & $\begin{array}{l}\text { Overcast, variable } \\
\text { illumination }\end{array}$ \\
\hline 2017.04 .28 & W & Overcast \\
\hline 2017.08 .29 & $S$ & Sunset \\
\hline 2018.04 .30 & W & $\begin{array}{l}\text { Overcast. Bud swelling } \\
\text { about to start. }\end{array}$ \\
\hline 2018.07.26 & S & Sunset \\
\hline 2018.08 .15 & $S$ & Overcast. Wet foliage. \\
\hline 2018.08 .17 & $S$ & Sunset \\
\hline 2018.08.20 & S & Overcast. Wet foliage. \\
\hline 2018.08 .26 & $S$ & Overcast. Wet foliage. \\
\hline
\end{tabular}

The gap $t(\theta)$ fraction was calculated for 4.5 degrees view zenith annuli and then fitted with an approximate model (Kuusk, 1995; Lang et al., 2017) by searching for plant area index $L^{\text {eff }}$ and leaf angle distribution parameter $\varepsilon_{l n}$ values using the least-squares estimation procedure nls in $\mathrm{R}$ software (R Core Team, 2016). The leaf area index was defined by Watson (1947) as the total one-sided area of leaf tissue per unit ground surface area. In this paper we present the plant area index, since we did not correct our results for stems, branches and did not correct for clumping effects. Gap fraction values at view zenith angles $10^{\circ}<\theta<70^{\circ}$ were used for model fitting, since observations near the zenith are not sufficient for averaging and large errors in radiance measurements and in the $t(\theta)$ estimation can be present at large view zenith angles.

\section{Results and Discussion}

The leafless canopy gap fraction has been slowly decreasing since 2007 with the plant area index increasing from 0.92 to 1.24 (Figure 1, Table 2). The increase in $L^{\text {eff }}$ can be mainly related to the growth of tree stems and crowns. The forest stand understory tree layer removal was not captured in the photographic measurements. This can be explained by the small value of understory $L^{\text {eff. }}$. The effect of the removal of understory trees on $t(\theta)$ can also be obscured by the increase in catkin size as the bud swelling was about to start at the end of April 2018.

The plant area index for full foliage phenophase increased from 3.6 in 2008 to 5.8 in 2017 (Figure 1, Table 2). This increase includes contribution from the upper layer of trees and also the increased $L^{\text {eff }}$ of the understory. After removal of understory trees the $L^{\text {eff }}$ decreased and repeated measurements in the summer of 2018 estimated the plant area index within the range $4.5<L^{\text {eff }}$ $<4.8$. The photographic measurements in the summer of 2018 were carried out under clear blue sky after sunset and also under overcast sky. The narrow range of the $L^{\text {eff }}$ estimates for the summer of 2018 shows that if direct solar radiation is avoided the dependence of LinearRatio ${ }_{\mathrm{SC}}$ on illumination conditions is negligible, which was also previously found by Lang et al. (2017). 


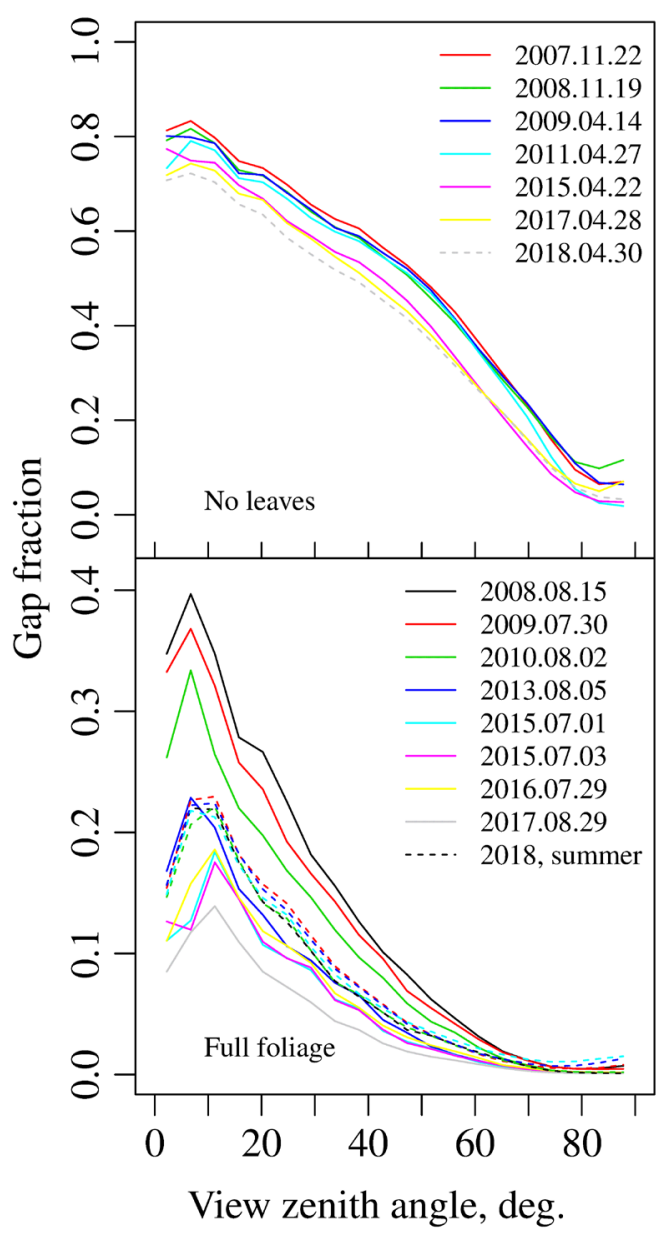

Figure 1. Gap fraction of the RAMI birch stand. Understory trees were cut in March 2018.

Our results confirm that correctly taken photographic measurements with consumer-grade digital cameras provide a reliable permanent record about tree canopy structure in forests. There are possible limits of LinearRatio ${ }_{\mathrm{SC}}$ when used for the calculation of gap fraction estimates for forest stands from hemispherical images. Compared to thresholding methods, LinearRatio $_{\mathrm{SC}}$ is more sensitive to the black canopy assumption which can result in increased gap fraction. With the increase in view zenith angle the probability decreases for finding sufficiently large gaps for taking unobscured sky samples for the above-canopy reference image construction. Therefore, the estimation errors increase at large view zenith angles. However, since the most informative part for the estimation of canopy indices is at mid- and small-view zenith angles the readings at $\theta<70^{\circ}$ can be ignored similarly to the plant canopy analyser LAI-2000. Regular digital cameras are not designed for photographic measurements but for photographic imaging. The responsibility of the camera operator is crucial for selecting such exposure settings that avoid any overexposure while keeping the maximum recorded pixel values in the mid part of the sensor dynamic range.

Table 2. Estimated values of the plant area in$\operatorname{dex} L^{\text {eff }}$ and foliage angle distribution parameter $\varepsilon_{l n}$ (Kuusk, 1995) using gap fraction data. Model residual standard error is in brackets.

\begin{tabular}{lcc}
\hline Date & $L^{\text {eff }}$ & $\varepsilon_{\text {ln }}$ \\
\hline 2007.11 .22 & $0.92(0.01)$ & $4.691(0.144)$ \\
2008.08 .15 & $3.59(0.07)$ & $3.902(0.213)$ \\
2008.11 .19 & $0.96(0.01)$ & $4.521(0.172)$ \\
2009.04 .14 & $0.94(0.01)$ & $4.279(0.215)$ \\
2009.07 .30 & $3.77(0.08)$ & $3.698(0.231)$ \\
2010.08 .02 & $3.98(0.06)$ & $3.123(0.169)$ \\
2011.04 .27 & $0.97(0.01)$ & $4.1190 .200)$ \\
2013.08 .05 & $4.93(0.13)$ & $3.240(0.271)$ \\
2015.04 .22 & $1.17(0.01)$ & $4.737(0.169)$ \\
2015.07 .01 & $5.25(0.16)$ & $3.3140 .299)$ \\
2015.07 .03 & $5.18(0.13)$ & $3.102(0.256)$ \\
2016.07 .29 & $5.01(0.13)$ & $3.034(0.266)$ \\
2017.04 .28 & $1.20(0.01)$ & $4.484(0.126)$ \\
2017.08 .29 & $5.84(0.15)$ & $3.067(0.252)$ \\
2018.04 .30 & $1.24(0.01)$ & $3.864(0.195)$ \\
2018.07 .26 & $4.77(0.13)$ & $3.408(0.282)$ \\
2018.08 .15 & $4.50(0.10)$ & $3.218(0.226)$ \\
2018.08 .17 & $4.76(0.13)$ & $3.441(0.287)$ \\
2018.08 .20 & $4.53(0.10)$ & $3.188(0.234)$ \\
2018.08 .26 & $4.54(0.13)$ & $2.938(0.319)$ \\
\hline & &
\end{tabular}




\section{Conclusions}

Hemispherical photographic measurement of the canopy gap fraction with a digital camera is a reliable method for long-term (> 10 years) monitoring of changes in forest canopy structure. Both tree growth and forest understory removal cause changes in the plant area index which are detectable in a mature deciduous broadleaf stand. This is guaranteed if the digital camera is operated as a radiance measurement device and data are processed with the LinearRatio $_{\mathrm{SC}}$ method. The images must be taken at fixed positions and during diffuse illumination conditions.

Acknowledgements. Measurements and analysis of the time series were partially supported by the Institutional Research Funding grant IUT21-04 and Estonian Defence Forces grant SLTTO19373. Jan Pisek received the Estonian Research Council Grant PUT1355. We would like to thank reviewers for their comments.

\section{References}

Anderson, M.C. 1964. Studies of the woodland light climate: I. The photographic computation of light condition. - Journal of Ecology, 52, 27-41.

Arumäe, T., Lang, M. 2018. Estimation of canopy cover in dense mixed-species forests using airborne lidar data. - European Journal of Remote Sensing, 51(1), 132-141.

Cescatti A. 2007. Indirect estimates of canopy gap fraction based on the linear conversion of hemispherical photographs: Methodology and comparison with standard thresholding techniques. - Agricultural and Forest Meteorology, 143(1-2), 1-12.

Coffin, D. 2014. Decoding raw digital photos in Linux. [WWW Document]. - URL http:// www.dechifro.org/dcraw/. [Accessed 11 November 2014].

Evans, G.C., Coombe, D.E. 1959. Hemispherical and woodland canopy photography and the light climate. - Journal of Ecology, 47, 103-113.
Fernandes, R., Plummer, S., Nightingale, J., Baret, F., Camacho, F., Fang, H., Garrigues, S., Gobron, N., Lang, M., Lacaze, R., LeBlanc, S., Meroni, M., Martinez, B., Nilson, T., Pinty, B., Pisek, J., Sonnentag, O., Verger, A., Welles, J., Weiss, M., Widlowski, J.L. 2014. Global leaf area index product validation good practices. Version 2.0. - Schaepman-Strub, G., Román, M., Nickeson, J. (eds.). Best Practice for SatelliteDerived Land Product Validation (p. 76): Land Product Validation Subgroup (WGCV/CEOS). DOI:10.5067/doc/ceoswgcv/lpv/lai.002.

Härkönen, S., Neumann, M., Mues, V., Berninger, F., Bronisz, K., Cardellini, G., Chirici, G., Hasenauer, H., Koehl, M., Lang, M., Merganicova, K., Mohren, F., Moiseyev, A., Moreno, A., Mura, M., Muys, B., Olschofsky, K., Del Perugia, B., Rørstad, P.K., Solberg, B., Thivolle-Cazat, A., Trotsiuk, V., Mäkelä, A. 2019. A climate-sensitive forest model for assessing impacts of forest management in Europe. - Environmental Modelling \& Software, 115, 128-143.

Kuusk, A. 1995. A fast, invertible canopy reflectance model. - Remote Sensing of Environment, 51, 342-350.

Kuusk, A., Lang, M., Kuusk, J. 2013. Database of optical and structural data for the validation of forest radiative transfer models. Kokhanovsky, A.A. (ed.). Light Scattering Reviews 7: Radiative Transfer and Optical Properties of Atmosphere and Underlying Surface. Berlin-Heidelberg, Springer, 109-148.

Kuusk, A., Lang, M., Kuusk, J., Lükk, T., Nilson, T., Mõttus, M., Rautiainen, M., Eenmäe, A. 2008. Database of optical and structural data for the validation of radiative transfer models. - Technical Report, 59 pp. Available online. http://www.aai.ee/bgf/jarvselja_db/ jarvselja_db.pdf.

Kuusk, A., Pisek, J., Lang, M., Märdla, S. 2018. Estimation of gap fraction and foliage clumping in forest canopies. - Remote Sensing, 10, 1153. DOI:10.3390/rs10071153.

Lallemand, F., Püttsepp, Ü., Lang, M., Luud, A., Courty., P.E., Palancade, C., Selosse, M.A. 2017. Mixotrophy in Pyroleae (Ericaceae) from Estonian boreal forests does not vary with light or tissue age. - Annals of Botany, 120 (3), 361-371. DOI:10.1093/aob/mcx054.

Lang, M., Kodar, A., Arumäe, T. 2013. Restoration of above canopy reference hemispherical image from below canopy measurements for plant area index estimation in forests. - Forestry Studies | Metsanduslikud Uurimused, 59, 13-27.

Lang, M., Kuusk, A., Mõttus, M., Rautiainen, M., Nilson, T. 2010. Canopy gap fraction estimation from digital hemispherical images using sky radiance models and a linear conversion method. - Agricultural and Forest Meteorology, 150(1), 20-29. 
Lang, M., Nilson, T., Kuusk, A., Pisek, J., Korhonen, L., Uri, V. 2017. Digital photography for tracking the phenology of an evergreen conifer stand. - Agricultural and Forest Meteorology, 246, 15-21.

Lukasová, V., Lang, M., Škvarenina, J. 2014. Seasonal changes in NDVI in relation to phenological phases, LAI and PAI of beech forests. - Baltic Forestry, 20, 248-262.

Nilson, T. 1971. A theoretical analysis of the frequency gaps in plant stands. - Agricultural and Forest Meteorology, 8, 25-28.

R Core Team. 2016. R: A language and environment for statistical computing. R Foundation for Statistical Computing, Vienna, Austria. [WWW Document]. - URL https://www.Rproject.org/. [Accessed 23 June 2016].

Watson, D.J. 1947. Comparative physiological studies on the growth of field crops: I. Variation in net assimilation rate and leaf area between species and varieties, and within and between years. - Annals of Botany, 11, 41-76.
Welles, J.M., Norman, J.M. 1991. Instrument for indirect measurement of canopy architecture. - Agronomy Journal, 83, 818-825.

Widlowski, J.L., Mio, C., Disney, M., Adams, J., Andredakis, I., Atzberger, C., Brennan, J., Busetto, L., Chelle, M., Ceccherini, G., Colombo, R., Côté, J.-F., Eenmäe, A., Essery, R., Gastellu-Etchegorry, J.-P., Gobron, N., Grau, E., Haverd, V., Homolová, L., Huang, H., Hunt, L., Kobayashi, H., Koetz, B., Kuusk, A., Kuusk, J., Lang, M., Lewis, P.E., Lovell, J.L., Malenovský, Z., Meroni, M., Morsdorf, F., Mõttus, M., Ni-Meister, W., Pinty, B., Rautiainen, M., Schlerf, M., Somers, B., Stuckens, J., Verstraete, M.M., Yang, W., Zhao, F., Zenone, T. 2015. The fourth phase of the radiative transfer model intercomparison (RAMI) exercise: Actual canopy scenarios and conformity testing. - Remote Sensing of Environment, 169, 418-437. 


\section{Lehtpuupuistu struktuurimuutuste jälgimine fotograafilise meetodi abil}

\section{Mait Lang ja Jan Pisek}

\section{Kokkuvõte}

Metsa kasv ja fotosünteetiliselt aktiivse kiirguse neeldumine on seotud lehepinnaindeksiga, mis on taimkatte struktuuri kirjeldav tunnus. Püsiproovitükkidel tehtud mõõtmised annavad võimaluse jälgida trende taimkatte struktuuris. Alates 2007. aastast on Järvseljal tehtud vertikaalsuunas digitaalseid poolsfääripilte (lisa I) rahvusvahelise kiirguslevimudelite võrdluseksperimendi RAMI (Widlowski et al., 2015) osaks olevas kaasikus (Kuusk et al., 2008; 2013). Mõõtmisi tehti nii kevadel lehtedeta puistus kui ka suvel, millal lehestik oli täiesti välja arenenud (Tabel 1). Poolsfääripiltide analüüsiks kasutati meetodit LinearRatio $_{\text {SC }}$ (Lang et al., 2010; 2013; 2017), mille abil saab arvutada taimkatte läbi- paistvuse nurkolenevuse $t(\theta)$, millest omakorda saadakse taimkatte indeks $L^{\text {eff }}$. $L^{\text {eff }}$ defineeritakse samuti kui lehepinnaindeks (Watson, 1947), kuid $t(\theta)$ põhjal saadud hinnangutes (Kuusk, 1995) on korrigeerimata lehestiku klasterdatuse ja taimkatte puitunud osa mõju. Selgus, et 1) puistu kasv ja võrade suurenemine on läbipaistvuse andmetes usaldusväärselt näha ja 2) raagus ajal tehtud läbipaistvustele ei avalda lehtpuuliikidest koosneva alusmetsa eemaldamine mõju (joonis 1, tabel 2), kuid suvisele läbipaistvusele on mõju tuntav. Saadud tulemused näitavad, et digitaalsed poolsfääripildid on usaldusväärne andmestik lehtpuupuistu struktuuri ja selle pikaajaliste muutuste uurimiseks. 
Appendix 1. Examples of photographic images taken at measurement point L1 in the RAMI birch stand.

Lisa 1. Poolsfääripilte RAMI kaasiku mõõtmispunktist L1.

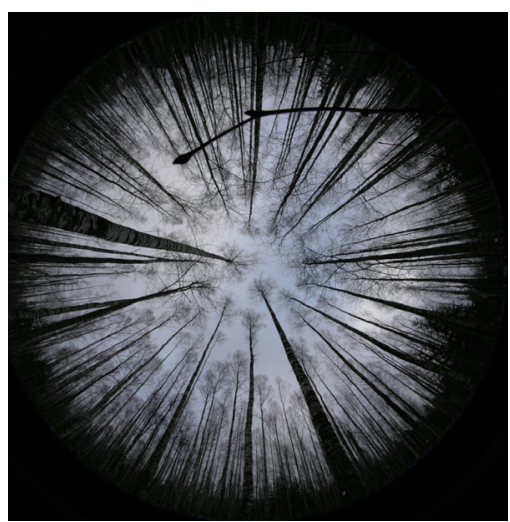

L1_22.11.2007_IMG_0186

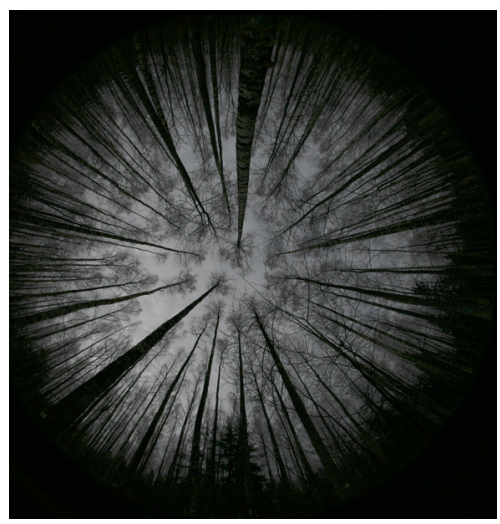

L1_22.04.2015_IMG_0550

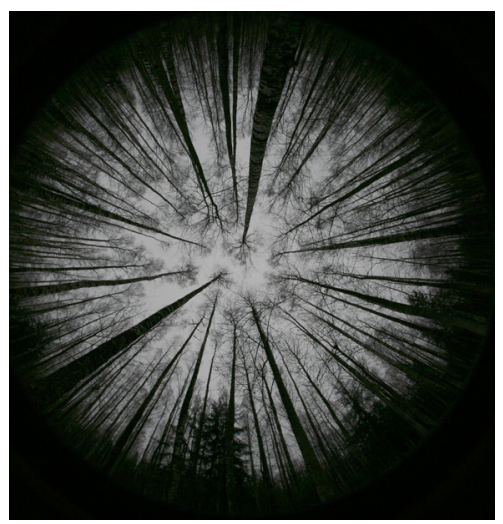

L1_30.04.2018_IMG_3133

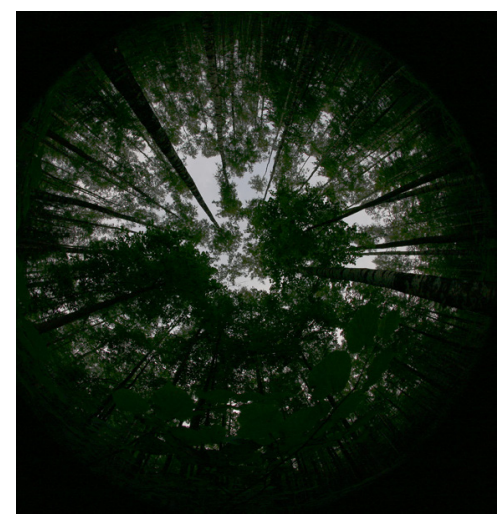

L1_15.08.2008_IMG_1093

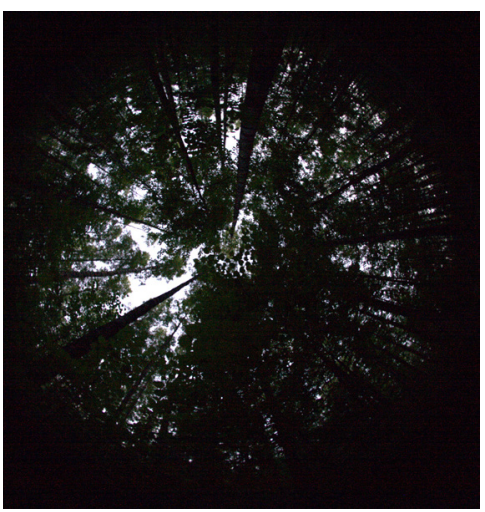

L1_03.07.2015_IMG_0643

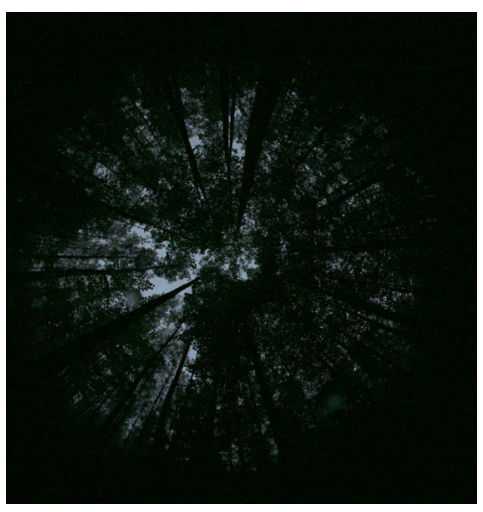

L1_26.08.2018_IMG_3426 